\title{
Fostering Learner's Critical Thinking Skills in EFL: Some Practical Activities
}

\author{
Assoc. Prof. Marsela Harizaj, PhD \\ Assoc. Prof. Veneranda Hajrulla, PhD \\ University of Vlora "Ismail Qemali", \\ Department of Foreign Languages, Albania
}

Doi: 10.19044/esj.2017.v13n29p126 URL:http://dx.doi.org/10.19044/esj.2017.v13n29p126

\begin{abstract}
Developing student's critical skills is one of the major concerns of foreign language teachers. Professional teachers and novice ones try to find ways to motivate their students. Developing communicative competence requires students to develop learning strategies and focus on language function and context. In every course assignments, learners understand and realize better that communication is not an easy thing. Developing accuracy and fluency in foreign language classes enhance students critical thinking too. However, What is critical thinking? What is the perception of learners about it? What communicative activities can foreign language teachers use in the classroom to enhance student's critical thinking? These are some research questions that this paper brings in focus, from theory to practice. The study is based on observations in EFL classes. From observations, it was found that developing critical thinking skills help learners to enhance their communication, enlarge their vocabulary, and help them to learn how to use language for different purposes in a variety of contexts. Foreign language teachers can help learners develop critical thinking skills. In this paper, some suggestions for foreign language teachers to use practical activities to foster critical thinking will be presented. Thus, in English language learning and teaching contexts, critical thinking becomes more dynamic.
\end{abstract}

Keywords: Language acquisition, critical thinking, communicative competence

\section{The Importance of Critical Thinking Skills}

There are various factors that affect student's ability to communicate in EFL/ESL classes. Here, we can mention motivation, classroom environment, and other factors such as teaching and learning contexts. Good teachers know how to challenge students (Ur, 1996). A good language 
teacher adopts methods and methodology according to a student's learning styles. Through this way, students are motivated to learn more and to involve themselves frequently in group or team-work. One of the factors that affect learner's communication is the learner's ability to think and act critically. Through critical thinking, learners develop the ability to communicate in English very well. Therefore, fostering critical thinking stimulates autonomous learning. Language learning is not an easy process. Exploiting means and possibilities of practicing language in the classroom is one of the teacher's and learner's concerns too.

There are different definitions of critical thinking skills, but the essence of the meaning is the same: the ability to think logically in an inquiry way. Critical thinking refers to the ability of individuals to take charge of their own thinking and develop appropriate criteria and standards for analyzing their own thinking. (Elder \& Paul, 1994) Tasks and assignments used in class affect student's perception of the language. The role of the teacher in a language class is very important.

It is the teachers' role to teach learners not just language skills, but also critical thinking skills. Through reading a passage, the learners use their critical skills to analyze and understand a passage. Sometimes they use these skills unconsciously. In the course of writing an assignment, these skills are utmost helpful for learners. Recently, the fostering learners' critical thinking is considered to be one of the teacher's tasks. Critical thinking skills make students reflect and to become creative. Through critical thinking, students become autonomous and self-confident. Critical thinking skills can be taught at all levels of studies from secondary and high -school students to university students as well.

\section{Teaching and Learning Contexts}

Nowadays, different methods of teaching are applied to teach students how to think critically. This strategy is being applied not just in foreign language, but in other subjects as well. In EFL classes, the learner tries to relate all knowledge and put in practice what is learned. A language teacher based on language curriculum exposes students to communicative activities, simulations, and other role-playing and problem-solving activities. Since the main aim of learning a language is to be used in and for communication, it is very important to use an effective teaching methodology.

Traditional language classroom, based on translation method, is replaced with communicative one. The design and selection of teaching methods must take into account not only the nature of the subject matter, but also how students learn (Davis, 1997). Nowadays, the concept of learnercentered classes is feasible. Learning English language and practicing it 
means negotiation. While the teacher explains something new, students take notes. They should learn to become successful listeners and thinkers. The teacher should take time to think which strategy works best to adopt his/her teaching method. The teacher's task primarily is to develop students thinking skills in problem solving. On the other hand, students should be aware of independent thinking, thus, autonomous learning. If they are trained well, they will be successful learners.

As the aim of teaching and learning is focused on Communicative Language Teaching and communicative competence, it is important for both the teacher and the learner to focus on this aspect. The role of the teacher is indispensable for the learner to enhance communicative competence. Communicative competence includes different aspects of language knowledge.

According to Richards (2006:3), communicative competence includes the following aspects of language knowledge:

$>\quad$ Knowing how to use language for a range of different purposes and functions

$>\quad$ Knowing how to vary our use of language according to the setting and the participants (knowing when to use formal and informal speech or when to use language appropriately for written as opposed to spoken communication)

$>\quad$ Knowing how to produce and understand different types of texts ( narratives, reports, interviews, conversations)

$>\quad$ Knowing how to maintain communication despite having limitations

in one's language knowledge ( through using different kinds of communication strategies)

The task of the teacher is to help the language learner master his/her language skills. Teachers are responsible for promoting critical thinking in the learners other than helping them to go from one educational level to the next. (Lipman, 2003) Language is a vivid thing that must be used continuously. All these aspects of language knowledge that a learner has to master, requires the use of different strategies by a learner. In such a case, the teacher has to use his/her own strategies to make students understand what learning strategies they have to use, how to develop thinking skills, and how to use them wisely for different purposes and in different situations.

\section{Some Practical Activities to Foster Critical Thinking}

This paper is based on the experience and observations of English language classes. It can be mentioned that fostering and equipping students with critical thinking competence is not a matter of one class, but of many classes starting from the use of simple activities to more problem solving activities. In university level in EFL classes, students use their creative 
thinking abilities in different ways and for different purposes. From experience, it was noted that if the teacher does not stimulate students, they will not be willingly to participate and collaborate with others.

In a communicative classroom, all the participants are collaborative. Effective learning depends on effective teaching. Teaching includes passion, ability, skills, active teaching, and interaction. A professional teacher is aware of students' needs. Teaching English is not merely to: explain the lesson, explain vocabulary, read aloud, give homework and that is done. An effective teacher should give instructions on how to learn this vocabulary, how to write an essay, how to write a composition, and so on. A well prepared teacher uses different skills in pedagogy in student-centred classes where the language context should be meaningful. The teacher assists and monitors the students while working on course assignments where the language is spoken and understood.

While thinking critically, students try to relate the known information with the unknown, draw schemes, and relate thoughts with meanings. It is the teacher's task to show them how to do this, to resolve and draw conclusions. Through critical thinking, students develop creativity and enlarge their vocabulary, language knowledge, and cultural knowledge as well. The question raised is Why? When? and How? to teach.

A student uses critical thoughts:

$>\quad$ in a reading passage by relating his/her own experience to that of the character of the passage;

$>\quad$ in a writing exercise whereby a student prepares an outline of opening, body and close remarks, taking into consideration the time given ( if it is a writing exercise given in class, 10-15 min or an essay that a student has to prepare at home);

$>\quad$ in a listening exercise (listen and fill in blank, draw conclusion);

$>\quad$ while speaking, example: debate, discussion (when the topic is known or unknown).

In all language skills, the student or the learner has to use his/her critical skills.

As we have mentioned above, critical thinking enhances communication in English language. The steps of fostering critical thinking skills begin with creating the conditions and preparing them to reinforce these skills. In a communicative classroom, even the activities are communicative. In an ideal academic language program, the objectives of the curriculum should go beyond linguistic factors to develop critical thinking among learners (Brown, 2004). The Common European Framework of References for Languages and The Albanian National Curriculum of Foreign Languages require the use of different meaningful activities where the learner relates what is learned with real life situations. 
Communicative methods that are used by teachers in the Albanian context are new, but practicing them by taking part in workshops and seminars make teachers understand the efficient strategies to teach language in EFL class. In the National Curriculum of Foreign Languages, the syllabus content, activities, language functions, and topics that a student learns during the cycle of studies beginning from beginner A1 to B2 (high school students' language level) are described.

In a foreign language class, language functions are classified. In addition, the learning program that includes the following aims included in the table below is offered:

\begin{tabular}{|l|l|}
\hline$>$ & Teaching and searching for information \\
\hline$>$ & Understanding statements, meaning and intention \\
\hline$>$ & Suggestions of action research or giving instructions \\
\hline$>$ & $\begin{array}{l}\text { Questions about likes or dislikes, approval or disapproval of } \\
\text { something, etc. }\end{array}$ \\
\hline
\end{tabular}

(adopted from The Albanian National Curriculum of Foreign Languages, 2000)

As a result, teachers use a range of practical communicative activities that require students to practice language, stimulate thoughts, stimulate critical thinking, enhance vocabulary, and make use of different language functions. Here, we can present some of the activities that a teacher can use to stimulate critical thinking. The difficulty of exercises and topics may vary from age to age, from one language level to another. It depends on the goal and the result of a language class.

\section{Some Practical Activities}

Here, we presented a number of practical activities to foster student's critical thinking:

\section{Information-Gap Activities}

Description: Students work in pairs, they share information with each-other (example: a listening or a speaking exercise).

2. Role -play Activities

Description: Students work in pairs, they play roles (example: situations from real life: in an airport, in a doctor's office, in a shop, etc.). Students have to write a dialogue upon the topic given. The language practiced may vary according to the aim. Students may practice the comparative of adjectives, adverbs of frequency, etc. The teacher uses flashcards, divides students in pairs, assign roles like Student A and Student B. Time: 5-10 min.

\section{Simulation Activities}

Description: Students work in groups, they play roles (example: situations from real life: at a railway station, in a mall, etc.). Simulation 
games embody roles; another difference is the number of students involved. Again, the teacher gives clues, divides students in groups, prepares the setting and gives time. Time 10-15-20 min., depends on language level.

4. Jigsaw Activities

In English textbooks, we can find different jigsaw activities. Again, the teacher divides the class into groups. Students collaborate with each other, share opinions, and discuss about the topic given. Even in a jigsaw activity, students share information. Example: exercises on a reading passage. There are given extracts from a reading passage and students have to work together to put the extracts in chronological order. The teacher has already prepared the flashcards for the students. Time given 5-10 min.

5. Surveys

Description: The teacher divides the class into groups. Students have to work together to write a report on a survey that they have prepared. Topics may vary for example: environmental issues, climate changes, pollution, etc. Students work together and share information to complete the task.

6. Interviews

Description: Usually, interviews are individual. Students prepare a set of questions for their mates on the given topic or about a topic of their own interest. Students prepare questions at home as a homework assignment and then use them in class.

* These activities may be used by English teachers in secondary classes as well as high school classes. The topics provided in the syllabus content of every English textbook are similar or almost the same, but the level of language is different. This means that if the teacher chooses a topic, for example Environment, the amount of vocabulary that a student from secondary school age 12-14 uses in comparison to a student of high school age 15-18 is less. However, structuring activities which stimulates thoughts is done in the same way.

* At University Level: Critical thinking skills are developed in different subjects and in different language skills. For example, in English classes with students at the University of Vlora in the $1^{\text {st }}, 2^{\text {nd }}$ and $3^{\text {rd }}$ year, some of the activities that are used to stimulate thoughts are project-works, essays, simulations, debates, and discussions.

$>\quad$ In different subjects such as Advanced English Level 1, 2, and 3, developing student's critical thinking is done through different reading and writing activities.

$>\quad$ While in other subjects such as Literature (American and British), students thoughts are developed through analyzing authors or novels.

$>\quad$ In Methodology $3^{\text {rd }}$ year Bachelor in English language, or Didactic $1^{\text {st }}$ year Master in English Language, students critical thoughts or, in other 
words, students critical competence is reinforced through different activities such as: simulation of English classes where the teacher (student in such a case) has to resolve different classroom situations concerning teaching, learning contexts or classroom problems.

In all the above mentioned activities, students use the known and the collected information, stimulate critical thinking, and uses language which is even the goal of learning English language.

\section{Conclusion}

In EFL/ESL classes, fostering student's critical thinking is one of the teacher's role and task. Stimulating thoughts make students to become aware of the potential of vocabulary that they are going to use. In every language context, students activate the known vocabulary. Speaking, reading, listening, and writing skills help students to enhance their communication. Through critical thinking, students learn independently and make their own decisions in various tasks.

However, there are various factors that motivate and affect foreign language learners' critical thinking. The ability to think is a basic requirement for students' success in inquiry learning (Clark \& Starr, 1991). The professional teacher uses activities to involve students in collaborative learning. It is very important for a foreign language learner to first improve his/her critical skills and then to use these skills to improve his/her language skills. From the activities mentioned above, students find themselves interacting, collaborating, and using language. Fostering critical skills may happen in different language levels with different student's age at any time. Well prepared interactive-based activities help students to understand the learning process and enhance communicative competence. Learners become aware of the language potential and their capacity to improve language proficiency.

\section{References:}

1. Brown, H. D. (2004). Some practical thoughts about studentssensitive critical pedagogy. The Language Teacher, 28(7), 23-27.

2. Clark, L.H. \& Starr, S. I. (1991). Secondary and Middle School Teaching Methods. Macmillian Publishing Company, New York.

3. Davis, J. R. (1997). Better teaching, more learning. Phoenix, Arizona: American Council on Education \& Oryx Press.

4. Elder, L. \& Paul, R. (1994). Critical thinking: Why we must transform our teaching. Journal of Developmental Education.

5. Harizaj, M. (2010). "Student's Critical Thinking in student-centered classes, Aftësimi i mendimit Kritik dhe Krijues të nxënësve të gjuhës së huaj nëpërmjet mësimdhënies me në qendër nxënësin”. III 
International Conference: Linguistic researches. Albanology Institute. Tiranë.

6. Lipman, M. (2003). Thinking in education. New York: Cambridge University Press.

7. National Curriculum of Foreign Languages Kurrikula Kombëtare e Gjuhëve Moderne për Arsimin Publik Parauniversitar (2000). Toena.

8. Richards, Jack C. \& Renandya, Willy, A. (2002). Methodology in Language Teaching. An Anthology of Current Practice. Cambridge University Press.

9. Richards, Jack C. (2006). Communicative Language Teaching Today. Cambridge University Press.p.3

10. Ur, P. (1996). A course in language teaching: Practice and theory. Cambridge: Cambridge University Press. 